\title{
Do we need cardiovascular risk assessment tools?
}

\author{
Abdulhalim J. Kinsara* \\ Head of Adult cardiology, King Saud bin Abdul-Aziz University for Health Sciences, King Abdul Aziz Medical City, Saudi Arabia
}

Troponin $\mathrm{T}$ and I had both diagnostic and prognostic value, However, it both reflect a myocardial injury. Work in progress to identify markers which can address the atherosclerosis process, before the myocardial damage occurs. Risk assessment is an important step in the management of CAD patients. Different factors in the history e.g. previous use of Aspirin or different forms of ECG changes such as diffuse ST depression have been associated with high mortality. The rise in markers like troponin has shown similar associated mortality and added prognostic information in terms of short and long term mortality to the clinical and ECG variables and constitute key elements of the Global Registry of Acute Coronary Events risk calculation (GRACE). High sensitivity cardiac troponin $\mathrm{T}$ has greater prognostic accuracy than troponin I [1]. Both types of troponin form the main corner of recommendation of both European and American guidelines of ACS [2]. Multiple biomarkers confer additional prognostic value to troponin like serum creatinine and glomerular filtration rate. Natriuretic peptides have been shown to provide prognostic information on top of cardiac troponin [3]. To some extent, the same applies to highsensitivity C-reactive protein and midregional pro-adrenomedullin, growth differentiation factor 15 and copeptin. [4]

However, troponin reflects an occurring injury. Researchers are working to identify markers that relate to the atherosclerosis process in the hope of preventing an acute event, screening populations and possibly having a therapy targeting particular patient. Two markers, which are commercially available and measured using ELISA test system have been tested. One is: phospholipase A2 enzymes (sPLA2IIA), in which increase of the level of cell expression in early and late atherosclerotic lesions, had been linked with recurrent events and adverse outcomes in patients with stable CAD [5-8], and increased risk of recurrent cardiac events and death in patients presenting with acute coronary syndromes [9-10]

The second maker is Gamma-Prime Fibrinogen, which via its binding site for thrombin and clots may be a risk factor for cardiovascular disease. An association has been found between gamma-prime fibrinogen concentrations and prevalence of coronary artery disease [11-13]. However, the assessment of these markers has so far not been shown to improve patient management and their added value in risk assessment on top of the current risk calculation seems marginal. Therefore, the routine use of these biomarkers for prognostic purposes cannot be recommended at the present time [2].

Copyright: (C2016 Kinsara AJ. This is an open-access article distributed under the terms of the Creative Commons Attribution License, which permits unrestricted use, distribution, and reproduction in any medium, provided the original author and source are credited.

\section{References}

1. Haaf P, Reichlin T, Twerenbold R, Hoeller R, Rubini Gimenez M, et al. (2014) Risk stratification in patients with acute chest pain using three high-sensitivity cardiac troponin assays. Eur Heart J 35: 365-375. [Crossref]

2. Roffi M, Patrono C, Collet JP, Mueller C, Valgimigli M, et al. (2016) 2015 ESC Guidelines for the management of acute coronary syndromes in patients presenting without persistent ST-segment elevation: Task Force for the Management of Acute Coronary Syndromes in Patients Presenting without Persistent ST-Segment Elevation of the European Society of Cardiology (ESC). Eur Heart J 37: 267-315. [Crossref]

3. Thygesen K, Mair J, Mueller C, Huber K, Weber M, et al. (2012) Recommendations for the use of natriuretic peptides in acute cardiac care: a position statement from the study group on biomarkers in cardiology of the ESC working group on acute cardiac care. Eur Heart J33(16):2001-2006. [Crossref]

4. Maisel A, Mueller C, Neath SX, Christenson RH, Morgenthaler NG, et al. (2013) Copeptin helps in the early detection of patients with acute myocardial infarction: primary results of the CHOPIN trial (Copeptin Helps in the early detection of Patients with acute myocardial INfarction). J Am Coll Cardiol 62(2):150-160. [Crossref]

5. Mallat Z, Lambeau G, Tedgui A (2010) Lipoprotein-associated and secreted phospholipases Aâ,, in cardiovascular disease: roles as biological effectors and biomarkers. Circulation 122: 2183-2200. [crossref]

6. Rosenson RS, Hurt-Camejo E (2012) Phospholipase A2 enzymes and the risk of atherosclerosis. Eur Heart J 33: 2899-2909. [Crossref]

7. Kugiyama K, Ota Y, Takazoe K, Moriyama Y, Kawano H, et al. (1999) Circulating levels of secretory type II phospholipase A (2) predict coronary events in patients with coronary artery disease. Circulation 100: 1280-1284. [Crossref]

8. Koenig W, Vossen C, Ziad M, Brenner H, Benessiano J, et al. (2009) Association between type II secretory phospholipase A2 plasma concentrations and activity and cardiovascular events in patients with coronary heart disease. Eur Heart J30 (22):27422748. [Crossref]

9. Ryu SK, Mallat Z, Benessiano J, Tedgui A, Olsson AG, et al. (2012) Phospholipase A2 enzymes, high-dose atorvastatin, and prediction of ischemic events after acute coronary syndromes. Circulation 125: 757-766. [Crossref]

10. Lind L, Simon T, Johansson L, Kotti S, Hansen T, et al. (2012) Circulating levels of secretory- and lipoprotein-associated phospholipase A2 activities: relation to atherosclerotic plaques and future all-cause mortality. Eur Heart J 33 (23):2946-2954. [Crossref]

11. Cheung E, Vos H, Kruip M, den Hertog H, Jukema J, et al. (2009) Elevated fibrinogen? ratio is associated with cardiovascular diseases and acute phase reaction but not with clinical outcome. Blood 114(20):4603-4604. [Crossref]

12. Lovely RS, Kazmierczak SC, Massaro JM, D’Agostino RB Sr, O’Donnell CJ, et al (2010) Gamma' fibrinogen: evaluation of a new assay for study of associations with cardiovascular disease. Clin Chem 56: 781-788. [Crossref]

13. Appiah D, Schreiner PJ, MacLehose RF, Folsom AR (2015) Association of Plasma $\hat{I}^{3}$ ' Fibrinogen with Incident Cardiovascular Disease: The Atherosclerosis Risk in Communities (ARIC) Study. Arterioscler Thromb Vasc Biol 35: 2700-2706. [Crossref]

Correspondence to: Abdulhalim J. Kinsara, Ass Professor, Head of Adult cardiology, King Saud bin Abdulaziz University for Health Sciences, COM-J, King Abdul Aziz Medical City- WR. King Faisal Cardiac center, Saudi Arabia, Tel: 966-12-2266666; Fax 920008668; E-mail: kinsaraaj@ngha.med.sa

Received: October 25, 2016; Accepted: November 08, 2016; Published: November 11, 2016 